\title{
PEMBERDAYAAN USAHA KECIL MENENGAH MELALUI MANAJEMEN PEMBUKUAN PADA KELOMPOK TUKANG MEBEL KECAMATAN PERCUT SEI TUAN
}

\author{
Syahreza Alvan ${ }^{1 *}$, Irma Novrianty Nasution $^{1}$, Syahrurahman Djayusman $^{2}$ \\ ${ }^{1 *}$ Jurusan Teknik Bangunan, Fakultas Teknik, Universitas Negeri Medan, Medan \\ ${ }^{2}$ Program Studi Manajemen, Fakultas Ekonomi, Universitas Sumatera Utara, Medan \\ *Penulis Korespodensi : syahrezalvan@gmail.com
}

\begin{abstract}
Abstrak
Pemerintah memberi perhatian yang besar terhadap perkembangan Usaha Mikro Kecil dan Menengah (UMKM). Masalah yang sering dihadapi oleh para pelaku UMKM antara lain mengenai pemasaran produk, teknologi, pengelolaan keuangan, kualitas sumber daya manusia dan permodalan. Salah satu masalah yang sering kali terabaikan oleh para pelaku bisnis UMKM yaitu mengenai pengelolaan keuangan. UMKM industri mebel di kota Medan perlu diberi pelatihan pembukuan dan akuntansi yang layak dan benar, maka akan memungkinkan mereka untuk memperoleh kredit UMKM bersubsidi dari pemerintah yang akan meningkatkan keberhasilan usaha baik dalam pengelolaan dana keuangan usaha atau pun kemampuan memproduksi produk dalam kuantitas yang lebih banyak dan kualitas yang lebih baik. Lokasi Mitra UMKM di Desa Bandar Khalifah Kecamatan Percut Sei Tuan Dusun XIV Seroja dan Dusun XVI. Permasalah tersebut dapat dipecahkan secara bersamaan dengan memberikan pelatihan pembukuan dan akuntansi dasar bagi UMKM tukang mebel Kecamatan Percut Sei Tuan. Pelatihan tersebut akan dimulai dengan pelatihan pembukuan, dilanjutkan dengan pelatihan pemahaman akuntansi secara mendasar, pelatihan penggunaan komputer dasar dan diakhiri dengan pelatihan pembukuan dan akuntansi terkomputerisasi. Dengan pelatihan yang dibuat selama 6 (enam) kali pertemuan mitra dapat membuat pembukuan yang baik dan mitra dapat membuat pengajuan Kredit Usaha Kecil (KUK) yang disediakan pemerintah.
\end{abstract}

Kata kunci: Pembukuan, tukang mebel, UMKM

\begin{abstract}
The government gives a great attention to the development of Micro, Small, Medium Enterprises. The problem often faced by Micro, Small, Medium Enterprises, among others, regarding the marketing of products, technology, financial management, human resources and capital. One problem that is often overlooked by businesses, namely Micro, Small, Medium Enterprises on financial management. The Micro, Small, Medium Enterprises furniture industries in the city of Medan need to be trained in accounting proper and correct, it will enable them to acquire Micro, Small, Medium Enterprises loans subsidized from the government that will enhance the success of businesses both in fund management business finances or the ability to produce products in quantities of more and better quality. Location Partner Micro, Small, Medium Enterprises in Desa Bandar Khalifah District of Percut Sei Tuan Dusun XIV Seroja and Dusun XVI. These problems can be solved simultaneously by providing training in basic accounting for Micro, Small, Medium Enterprises of Percut Sei Tuan District. The training will begin with accounting training, followed by training in basic understanding of accounting, basic computer usage training and ends with computerized accounting training. With the training made for six meetings partners can make a good accounting and partners can make filing Micro Business Credit Program provided by the government.
\end{abstract}

Keywords: Accounting, furniture's craftmanship, Micro, Small, Medium Enterprises

\section{PENDAHULUAN}

Pemerintah selama dua dekade terakhir memberi perhatian yang sangat besar terhadap perkembangan Usaha Mikro Kecil dan Menengah (UMKM). Bertahannya UMKM terhadap krisis moneter yang terjadi pada tahun 1998 menjadi alasan utama mengapa pemerintah menaruh perhatian yang besar terhadap UMKM. Sejak krisis yang terjadi pada tahun 1998, hampir 70\% usaha besar mengalami kebangkrutan dan banyak melakukan PHK. Pada periode yang sama sebagian besar UMKM mampu bertahan hidup dan sangat berperan dalam mengurangi tingkat pengangguran. Peranan UMKM dalam perekonomian Indonesia dapat dilihat dari kedudukannya pada saat ini dalam dunia usaha. Urata (2000) membagi kedudukan UMKM sebagai (1) 
pemain utama dalam kegiatan ekonomi di berbagai sektor, (2) penyedia lapangan kerja terbesar, (3) pemain penting dalam pengembangan kegiatan ekonomi daerah dan pemberdayaan masyarakat, (4) pencipta pasar baru dan inovasi. UMKM yang sudah go internasional memberikan sumbangan dalam menjaga neraca pembayaran melalui sumbangannya dalam menghasilkan ekspor.

Salah satu upaya pemerintah memberdayakan UMKM berupa paket kebijakan ekonomi pada bulan maret tahun 2002. Paket kebijakan pemerintah ini memfokuskan pada empat hal yaitu, memberikan pelayanan dan kemudahan bagi UMKM, melakukan restrukturisasi UMKM, membuka akses pelayanan perbankan khusus bagi UMKM dan melakukan pembinaan sumberdaya manusia. Namun program pemerintah ini tidak dapat berjalan sendiri tanpa dukungan dari berbagai pihak yang terkait seperti, perguruan tinggi, departemen perindustrian dan perdagangan, BUMN, Departemen Koperasi dan UMKM.

Masalah yang sering dihadapi oleh para pelaku UMKM antara lain mengenai pemasaran produk, teknologi, pengelolaan keuangan, kualitas sumber daya manusia dan permodalan. Salah satu masalah yang sering kali terabaikan oleh para pelaku bisnis UMKM yaitu mengenai pengelolaan keuangan. Dampak dari diabaikannya pengelolaan keuangan mungkin tidak terlihat secara jelas, namun tanpa metode akuntansi yang efektif, usaha yang memliki prospek untuk berhasil dapat menjadi bangkrut.

Salah satu UMKM yang berkembang dan memiliki prospek untuk berhasil dan go internasional adalah industri mebel. Industri mebel adalah industri yang mengolah bahan baku atau bahan setengah jadi dari kayu, rotan, dan bahan baku alami lainnya menjadi produk barang jadi mebel yang mempunyai nilai tambah dan manfaat yang lebih tinggi. Industri mebel di Indonesia tersebar hampir di seluruh provinsi, dengan sentra-sentra yang cukup besar terletak di Jepara, Cirebon, Sukoharjo, Surakarta, Klaten, Pasuruan, Gresik, Sidoarjo, Jabodetabek, dan lain-lain. Di kota Medan juga telah mulai berkembang sentra industri mebel diluar pulau Jawa. Hal ini dimungkinkan semakin tingginya permintaan mebel perkantoran dan perumahan dengan tipe nonpabrikasi (customize).

Seperti umumnya UMKM lain, industri mebel di kota Medan memiliki keterbatasan dalam hal memproduksi barang dalam hal kuantitas dan kualitas yang dibutuhhkan pasar domestik dan ekspor. Hal ini disebabkan keterbatasan modal untuk memperoleh peralatan dan pelatihan yang dibutuhkan. Pemerintah Indonesia sudah sangat aktif mendukung program permodalan / kredit untuk UMKM dengan bunga yang di subsidi pemerintah, namun penyaluran kredit tersebut selalu terkendala dalam hal pembukuan keuangan UMKM yang hampir seluruhnya tidak pernah melakukan pembukuan yang layak, sehingga tidak memungkinkan kredit UMKM pemerintah tersebut bisa tersalurkan dengan baik.
Jika UMKM industri mebel di kota Medan diberi pelatihan pembukuan dan akuntansi yang layak dan benar, maka akan memungkinkan mereka untuk memperoleh kredit UMKM bersubsidi dari pemerintah yang akan meningkatkan keberhasilan usaha baik dalam pengelolaan dana keuangan usaha atau pun kemampuan memproduksi produk dalam kuantitas yang lebih banyak dan kualitas yang lebih baik.

Penerapan pembukuan dan akuntansi yang baik dalam industri mebel akan membuat para pelaku usaha bisa menampilkan neraca keuangan usaha beserta laporan laba rugi usaha dalam suatu periode tertentu. Hal tersebut paling dibutuhkan dalam pengajuan kredit UMKM ke perbankan. Selain itu penerapan pembukuan dana kuntansi yang layak dalam UMKM industri mebel juga akan membuat pelaku usaha bisa melihat secara lebih jelas berbagai jenis informasi keuangan yang berguna dalam pengambilan keputusan antara lain informasi kinerja perusahaan, informasi penghitungan pajak, informasi posisi dana usaha informasi perubahan modal pemilik, informasi pemasukan dan pengeluaran kas. Informasi-informasi tersebut memungkinkan para pelaku UMKM dapat mengidentifikasi dan memprediksi area-area permasalahan yang mungkin timbul, kemudian mengambil tindakan koreksi tepat waktu. Tanpa informasi akuntansi, masalah-masalah yang sedianya dapat dihindari atau dipecahkan justru menjadi penyebab kebangkrutan usaha tersebut. Untuk itu, penting sekali bagi pengusaha untuk dapat membaca dan menafsirkan informasi akuntansi. Paling tidak, setiap pengusaha dapat menghitung untung ruginya, dan yang paling penting untuk dapat memahami makna untung atau rugi bagi usahanya

\section{Kondisi Mitra}

Desa Bandar Khalifah Kecamatan Percut Sei Tuan Dusun XIV Seroja (bengkel Mebel Project) dan Dusun XVI (bengkel Karya Utama) yang sebagian besar masyarakatnya sebagai tenaga tukang, baik tukang bangunan maupun tukang mebel. Pada umumnya tukang-tukang di Desa Bandar Khalifa bekerja pada bengkel-bengkel mebel yang ada di sekitar kota Medan. Selain itu, ada pula beberapa kepala tukang mebel yang memiliki usaha mandiri dengan membuka bengkel mebel sendiri, baik di Dusun XIV Seroja maupun di luar tempat tinggalnya dengan cara membangun kerjasama dengan mitra yang lebih besar ataupun menyewa tempat untuk dijadikan bengkel kerja. Latar belakang pendidikan tukang mebel terutama kepala tukang atau mandor adalah lulusan Sekolah Menengah dan Sekolah Menengah Kejuruan. Dengan begitu, para tukang memiliki kemampuan dasar keilmuan meskipun kurang memadai dan keterampilan didapat dari pengalaman bekerja saja.

Di Desa Bandar Khalifah dan sekitarnya, masyarakat sering kali memesan mebel kepada para tukang mebel yang ada. Produk mebel dipesan pada saat-saat tertentu misalnya untuk keperluan pernikahan, melengkapi rumah baru, melengkapi 
ruangan di rumah-rumah ibadah dan sekolah, hingga mebel di perkantoran, serta booth pameran dan ATM dari instansi perbankan. Pekerjaan mebel dilakukan oleh kepala tukang atau mandor dan dibantu oleh beberapa tukang yang memiliki tingkat keahlian di bawah mandor. Biasanya mereka membentuk kelompok-kelompok tukang dan pesanan produk mebel dilakukan melalui jasa mandor sebagai pemimpin kelompok tersebut. Anggota kelompok tukang biasanya memiliki kemampuan dasar dan tidak menyeluruh dengan sifatnya yang musiman. Dengan kemauan dan keinginan bekerja dengan pengalaman seadanya mereka menerima pekerjaan, tentunya dengan biaya yang lebih murah agar klien tertarik. Namun, ada juga tukang yang memiliki kemampuan yang lebih baik dan berkualitas, pasar penjualan produknya sudah jelas dan biasanya memiliki pelanggan tetap.

Dengan kemampuan yang dimiliki para tukang dan pangsa pasar yang luas di bidang mebel, tentunya usaha ini pantas untuk dikembangkan dan dipertahankan kelangsungannya. Dalam rangka menjaga kelangsungan usaha, para tukang harus memiliki bekal manajemen keuangan yang baik dan rapi agar hasil jerih payah selama bekerja tidak habis dengan percuma. Permasalahan yang sangat nyata ditemui pada kelompok tukang adalah masalah manajemen keuangan karena tiap kelompok tukang menerima honor mingguan dan ketika membutuhkan modal untuk melanjutkan pesanan baru akan terhalang oleh masalah ini. Dengan kurangnya kemampuan mengelola keuangan secara baik maka produksi dan kelangsungan usaha akan terhenti. Dan sumber pendapatan masyarakat di sekitar kampung juga terhenti dan timbul masalah baru yaitu pengangguran. Dengan pengelolaan sistem keuangan yang baik diharapkan masyarakat sekitar kampung tertarik untuk bekerja lebih giat dan berusaha membuka peluang baru dan menjadi pesaing bagi kelompok-kelompok yang telah terbentuk lebih dahulu.

\section{Permasalahan Mitra}

Idealnya UMKM mebel Kota Medan mempunyai kemampuan yang memadai untuk memenuhi kebutuhan pelanggan / pesanan pasar baik domestik maupun pasar ekspor. Tetapi pada kenyataannya para pelaku UMKM ini memiliki keterbatasan terutama dalam hal modal untuk memperoleh bahan baku dan peralatan serta pelatihan pembuatan mebel yang lebih baik. Termasuk dalam permasalahan adalah ketidakmampuan pelaku UMKM mebel untuk menetapkan harga pokok produksi yang sebenarnya. Jika dibiarkan berlarut maka para pelaku UMKM mebel ini cepat atau lambat akan minimum kebangkrutan yang ujungnya akan menambah pengangguran di kota Medan.

\section{Identifikasi Permasalahan yang Dihadapi Mitra}

a. Kelompok pelaku UMKM mebel belum pernah ataupun tidak memiliki pengetahuan mengenai pembukuan keuangan. b. Kelompok pelaku UMKM mebel tidak memiliki kemampuan dan pengetahuan dalam hal akuntansi yang baik dan benar dalam hal pengelolaan sumberdaya keuangan usaha.

c. Kelompok pelaku UMKM mebel tidak memiliki pengetahuan dan kemampuan yang cukup untuk memperoleh tambahan modal kerja dari perbankan atau pemerintah.

\section{Justifikasi Permasalahan Bersama mitra}

Hasil diskusi yang dilakukan bersama kelompok tukang mebel, Lurah, Kepala Lingkungan, dan kelompok masyarakat setempat menyatakan bahwa kelompok tukang mebel yang ada di lingkungan tempat tinggal mereka belum menarik minat pemuda setempat untuk ikut mengembangkan produk mebel. Disamping pengetahuan yang kurang juga kemampuan secara finansial belum mencukupi untuk mengambil peluang yang ada. Selain itu, pengalaman tukang-tukang lain menjadi tolok ukur dalam keberanian mengambil peluang pasar. Dengan begitu perlu diberi pemahaman dan pengetahuan akutansi dasar dan praktis kepada kelompok masyarakat terutama kelompok tukang yang sedang mengembangkan usahanya di bidang perkayuan atau mebel guna mencapai usaha yang mapan dan menjadi daya tarik bagi masyarakat di lingkungan sekitar usaha ini berkembang.

\section{METODE PELAKSANAAN}

Permasalahan utama yang dialami oleh UMKM tukang mebel Kecamatan Percut Sei Tuan adalah kemampuan untuk menentukan secara tepat besaran laba / rugi yang didapat selama suatu periode tertentu dan keterbatasan modal kerja. Permasalahan kemampuan menentukan laba / rugi usaha secara khusus berhubungan dengan penggunaan peralatan usaha yang memiliki batas umur pemakaian, penetapan beban biaya perlengkapan usaha yang habis terpakai dan penentuan biaya gaji untuk tenaga kerja dengan keahlian khusus yang dibutuhkan UMKM tukang mebel Kecamatan Percut Sei Tuan. Permasalahan keterbatasan modal kerja berhubungan dengan kemampuan keuangan UMKM tukang mebel Kecamatan Percut Sei Tuan untuk memperoleh bahan baku mebel dalam memenuhi permintaan konsumen.

Kemampuan UMKM tukang mebel Kecamatan Percut Sei Tuan dalam menghitung besaran laba / rugi dapat diperbaiki dengan suatu pelatihan pembukuan dan akuntansi dasar. Masalah keterbatasan modal kerja dapat diatasi dengan memperoleh kredit UMKM yang disubsidi pemerintah. Namun pengajuan kredit ke Bank tersebut membutuhkan UMKM tukang mebel Kecamatan Percut Sei Tuan untuk melakukan pembukuan yang benar dalam menjalankan usaha mengevaluasi kinerja, mengetahui posisi keuangan dan menghitung pajak.

Kedua masalah tersebut dapat dipecahkan secara bersamaan dengan memberikan pelatihan pembukuan dan akuntansi dasar bagi UMKM tukang mebel Kecamatan Percut Sei Tuan. Pelatihan tersebut akan dimulai dengan pelatihan pembukuan, 
dilanjutkan dengan pelatihan pemahaman akuntansi secara mendasar, pelatihan penggunaan komputer dasar dan diakhiri dengan pelatihan pembukuan dan akuntansi terkomputerisasi. UMKM tukang mebel Kecamatan Percut Sei Tuan akan menghadiri total 20 pertemuan yang masing-masing memakan waktu 2 jam dalam proses pelatihan pembukuan dan akuntansi dasar yang direncanakan diatas. Waktu pertemuan akan disesuaikan dengan ketersediaan waktu dari pihak UMKM tukang mebel Kecamatan Percut Sei Tuan.

Diakhir pelatihan, UMKM tukang mebel Kecamatan Percut Sei Tuan diharapkan sudah mampu menghitung laba / rugi dari usaha selama periode tertentu secara benar, cepat dan terkomputerisasi, mampu menyusun suatu laporan keuangan usaha yang terdiri neraca, laporan laba rugi, perhitungan pajak dan laporan perubahan modal. Dengan kemampuan tersebut diharapkan UMKM tukang mebel Kecamatan Percut Sei Tuan dapat memenuhi pesyaratan untuk mendapatkan tambahan modal kerja dari Bank melalui skema kredit UMKM yang disubsidi pemerintah.

\section{HASIL YANG DICAPAI}

Hasil yang telah dicapai dari bulan April 2016 sampai November 2016 adalah telah dilakukannya persiapan-persiapan seperti:

\section{Melakukan koordinasi dengan Kepala Desa}

Melakukan kunjungan dan koordinasi ke kantor kepala Desa Bandar Khalifah Kecamatan Percut Sei Tuan untuk melaporkan kegiatan IbM Tukang Mebel Kecamatan Percut Sei Tuan Dalam Pemberdayaan Usaha Kecil Menengah Melalui Manajemen Pembukuan.

\section{Melakukan Koordinasi dengan Mitra}

Melakukan koordinasi dengan mitra untuk melakukan sosialisasi kegiatan IbM Tukang Mebel Kecamatan Percut Sei Tuan Dalam Pemberdayaan Usaha Kecil Menengah Melalui Manajemen Pembukuan.

\section{Melakukan pelatihan pertama dengan mitra.}

Pengenalan materi yang disampaikan oleh narasumber. Pengenalan fungsi dan kegunaan dari kegiatan IbM Tukang Mebel Kecamatan Percut Sei Tuan Dalam Pemberdayaan Usaha Kecil Menengah Melalui Manajemen Pembukuan.

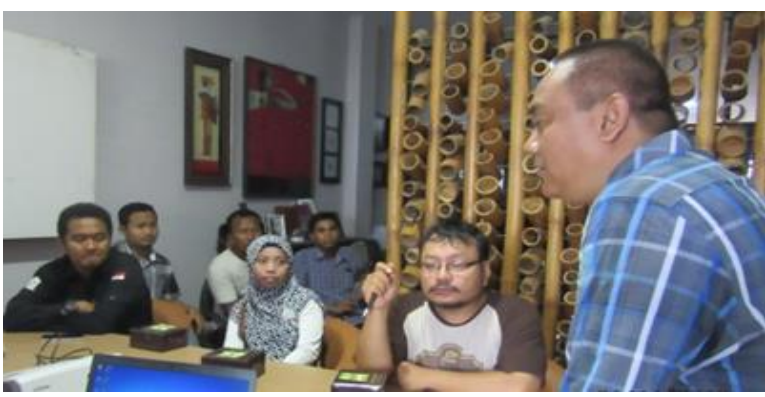

Gambar 1. Ketua Pelaksana memberikan pengarahan kepada mitra

\section{Melakukan pelatihan kedua dengan mitra.}

Pengenalan mitra dengan tim pendamping dan monev internal LPM Unimed. Penyerahan secara simbolis seperangkat PC, Meja Komputer, Kursi dan Printer disaksikan oleh tim pendamping dan tim monev internal LPM Unimed. Melakukan pelatihan dengan materi dasar - dasar pembukuan.

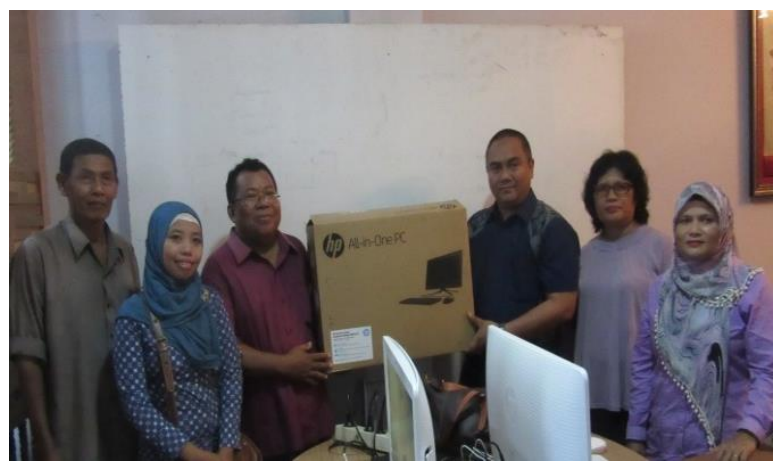

Gambar 2. Penyerahan Seperangkat PC secara simbolis dari ketua pelaksana kepada mitra di saksikan tim pendamping dan tim monev internal LPM Unimed

\section{Melakukan Pelatihan ketiga dengan mitra}

Materi pelatihan berupa pembuatan pembuakuan dasar dari pekerjaan mebel, yang digunakan dalam satu pekerjaan. Latihan menghitung pembelian material dan upah dalam satu pekerjaan agar dapat diketahui laba dari satu pekerjaan.

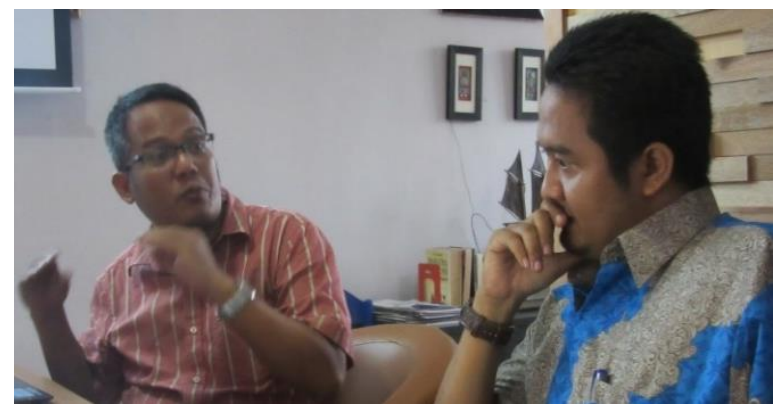

Gambar 3. Narasumber memberikan pengarahan kepada mitra

\section{Melakukan Pelatihan keempat dengan mitra}

Materi pengenalan program khusus untuk menyusun pembukuan. Materi pengenalan dasar excel. Latihan menggunakan excel untuk pembukuan dasar keuangan

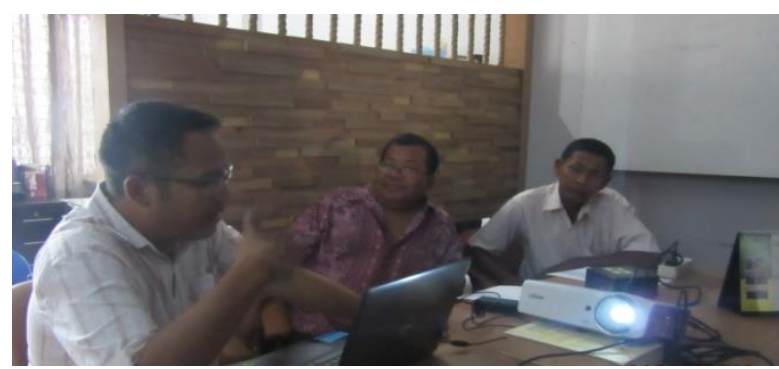

Gambar 4. Narasumber memberikan pengarahan kepada mitra 


\section{Melakukan Pelatihan kelima dengan mitra}

Memperkenalkan pihak perbankan Bank BRI kepada mitra kegiatan. Pihak Bank BRI memberikan pengarahan kepada mitra mekanisme pengajuan program pinjaman KUR pada Bank BRI. Diskusi dan sesi tanya jawab mitra dengan pihak bank BRI

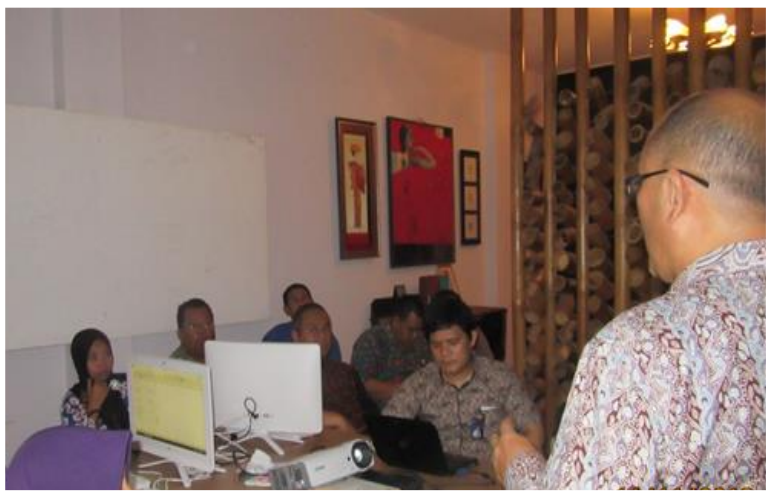

Gambar 5. Pihak Bank BRI memberikan pengarahan mekanisme memperoleh program pinjaman KUR pada Bank BRI kepada mitra.

\section{Melakukan Pelatihan ke enam dengan mitra}

Memeriksa latihan yang diberikan nara sumber. Latihan membuat pembukuan sederhana yang baik dan benar sesuai dengan syarat mekanisme program pinjaman KUR pada Bank BRI.

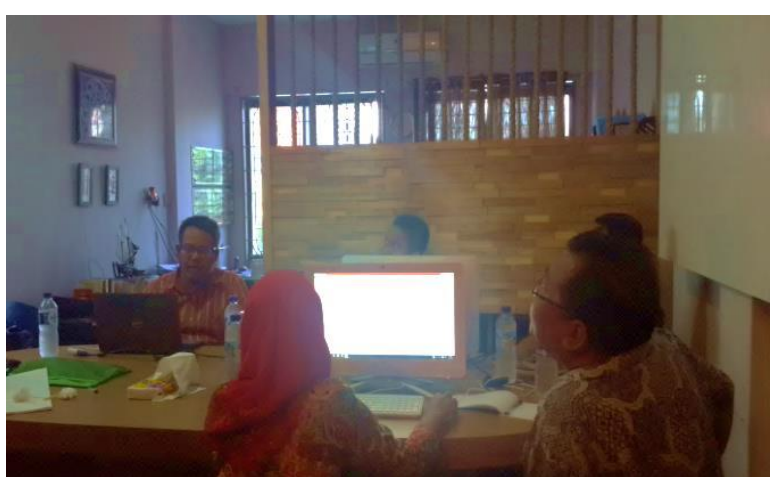

Gambar 5. Narasumber memberikan pengarahan kepada mitra

\section{RENCANA TAHAPAN BERIKUTNYA}

Rencana Tahapan berikutnya adalah:

1. Sesuai dengan kesepakatan antara tim pengabdian dengan kelompok mitra adalah akan membuat pembukuan yang baik dan benar untuk dapat mengajukan program pinjaman KUR pada Bank BRI.

2. Membuat pelatihan serupa di Desa Bandar Khalifah kecamatan Percut Sei Tuan dengan para pengusaha UMKM di desa tersebut agar para pengusaha UMKM dapat mengembangkan usahanya dengan lebih baik.

\section{KESIMPULAN}

Kesimpulan ang diambil dari kegiatan ini adalah:
1. Mitra sangat tertarik dengan kegiatan ini, hal ini dapat ditunjukkan dengan antusiasnya kelompok mitra tersebut dalam bertanya dan kehadiran.

2. Pada saat sosialisasi dengan seksama kelompok mitra mendengarkan tentang rangkaian kegiatan dan bahan paparan yang disampaikan baik oleh nara sumber ataupun Pihak Bank BRI.

\section{SARAN}

Sebaiknya kegiatan ini dapat dilakukan beberapa hari agar Pengusaha UMKM dapat membuat pembukuan yang baik dan benar.

\section{UCAPAN TERIMA KASIH}

Terima kasih disampaikan kepada LPM UNIMED yang telah mendanai keberlangsungan jurnal ini.

\section{DAFTAR PUSTAKA}

Urata, S. (2000). Policy Recommendation for SME Promotion in the Republic of Indonesia. JICA Senior Advisor to Coordination Minister of Economy, Finance and Industri, Jakarta. 